\title{
Balinese Women in The Cruise Ships Tourism Industry
}

I Made Darma Oka, Made Antara and I Gede Mudana

\author{
School of Postgraduate Study \\ Doctorate Degree in Tourism Udayana University \\ Coressponding author: darmaokaimade@yahoo.com
}

\section{ARTICLE INFO}

Received

01 November 2014

Accepted

10 February 2015

Available online

10 March 2015

\section{ABSTRACT}

As one of the most popular destinations for international tourists, Bali has attracted a sizeable and growing labor force in the tourism sector of the economy. This fact has triggered Balinese labor force to participate in such service industry. As a supplier of tourism labor force Bali has been increasingly successful in promoting the number of workers to be employed on cruise ships. The participation rate of Balinese women in cruise industry over the last four years has dramatically increased. The Balinese women's participation in cruise ship employment has brought major implications for their life and culture. Generally, the present study aimed to provide an overview of Balinese women employed on board of a cruise ship. More specifically, it examined (1) the strengths, weaknesses, opportunities, and threats faced by Balinese women working in cruise industry, (2) factors influencing them to work in the industry, and (3) the implications brought by such employment for their life and society. The present study used quantitative and qualitative data collected through economic, social, and cultural approach. The sample was comprised of 200 respondents selected using accidental sampling method. To answer the research questions, data collection was conducted through observation, interviews, as well as focus group discussion (FGD). The data on the strengths, weaknesses, opportunities, and threats faced by Balinese women on board of a cruise ship were analyzed using SWOT analysis, whereas the data on the factors influencing them to work in the cruise industry were analyzed using factor analysis. Finally, qualitative analysis was employed to analyze the data on the economic, social, and cultural implications for their life. The analysis showed that: (1) Balinese women were employed on board of a cruise linerpredominantly as support staff. The strengths of Balinese women cruise ship workers included being friendly, always smiling, being honest, being loyal, being responsible, and being highly skilled. Their weaknesses included having low motivation to get a high position, having low English proficiency level, and having insufficient self-confidence. The job opportunities were still high since women were generally reluctant to work in the cruise industry. The threats they faced included the lack of concern on the part of the government, agents providing poor services and unjustly treating applicants. (2) The factors influencing Balinese women to work in the cruise industry were of economic, social, and cultural. (3) The implications brought by the cruise ship employment for Balinese women were divided into three: economic implication, social implication, and cultural implication. Economic implication refers to their ability to help increase their family income. (b) Social implication refers to the fact that through employment in the cruise industry they could elevate their and their family social status. (3) cultural implication refers to their contribution to the preservation of their own culture (i.e. Balinese culture).

Keywords: Balinese women, tourism industry, cruise ships 


\section{Introduction}

\section{Background}

Working in a cruise ship is a trend today for the people of Bali. Balinese people have seen the fact that workers who work in the cruise ships have changed their standard of living and that of their families. This is evidenced by the fact that working in a cruise ship, they could meet their primary, secondary and tertiary needs more feasibly by building a more permanent home or buying a car. They realize that working in a cruise ship in addition to getting greater income than working in home country, they can travel out of the country, and are able to open their horizons. This fact motivates other Balinese workforce to be able to also work in cruise ships. This is in line with the research by Sunarsa (2010) which states that working in cruise ships has a promising prospect as long as they are able to do it because the salary received is greater than working in home country. However, lately there have been some cases causing concerns that struck Balinese workers who work in cruise ships such as the cases of abuse and rape, as well as the death of a Balinese labor while working in a cruise ship.

Bali as a tourism workforce producer has managed to increase the sending of Bali labors to cruises in 2010-2013. In terms of percentage, the level of participation of Balinese women who work in the cruise tourism industry from year to year has increased, although the level of participation is still less than $10 \%$, when compared to the male workforce (BP3TKI, 2014). Balinese women's involvement in the cruise tourism industry certainly gives implications to the advancement of tourism and environment of life both in terms of economy, social, and culture. The involvement of women in the cruise ship industry is an interesting phenomenon, because generally this tourism sector belongs to the male domain. The participation of Balinese women to work in the cruise tourism industry is influenced by social and economic factors. Social factors include age group, marital status, and education. Economic factors that can affect the motivation of women to work in the cruise tourism industry, for example, among others are due to the fact that women are forced to work out of economic necessities of their families or they want to help their husbands to supplement the family income. Even with the success of the family in achieving economic establishment of the family can cause the exit of women from the field of employment (Soedjono, 1986).

Empowerment of women in the cruise tourism industry is an interesting case because culturally tourism sector is in the public sector, which is based on the traditional division of labor (gender) a public sector is male-domain working area. The working area of women is in domestic sectors such as managing the household, washing, and cooking. Sukeni (2006) stated that although there is division of labor in the conventional way, but in reality especially for women, Bali is a lot different because since modern tourism is developed in Bali, Balinese women have participated in the public sector, such as working in the tourism industry. It is therefore interesting to study in depth about the implications of Balinese women who work in the cruise tourism industry to the environment in terms of economy, social, and culture.

\section{Research Objectives}

In general, this study aimed to give a general idea of the existence of Balinese women who work in the cruise tourism industry. Specifically, the purposes of this research are to:

1) Assess the presence of Balinese women who work in the cruise tourism industry from the aspects of the strengths, weaknesses, opportunities and threats they face,

2) Analyze the factors that motivate Balinese women to work in cruise tourism industry, and

3) Assess the economic, social, and cultural implications of Balinese women who work in the cruise tourism industry to tourism and life environment.

\section{Literature Review}

Balinese women's studies in the cruise ship industry interesting to discuss because of the involvement of women in the tourism sector is influenced by economic, social, and cultural factors. Several studies related to the 
issues discussed in the study include: Wilkinson and Pratiwi (1995) entitled "Gender and Tourism in an Indonesian Village"; Kalpika (1999), entitled "Women in Tourism Industry: A Case Study in the tourism area of Kuta, Ubud and Kintamani" explained that tourism has shifted the pattern of household labor in society Kuta, Ubud and Kintamani; Sari (2008), entitled Motivation of Balinese Women Workers in Melati Hotels in Ubud Tourism Area, Gianyar, Bali which examine the motivation of Balinese female workers working on jasmine hotels, as well as the influence of age, education, household income, marital status, asset ownership and working conditions of the motivation Balinese women in melati hotels in Ubud tourism area; as well as in research by Sadia and Oka (2012) entitled "Working motivation of Balinese workforce working in Mediterranean Shipping Company Cruise" it is argued that the working motivation of Balinese workforce to work in Mediterranean Shipping Company Cruise is dominant because of the economic motivation amounting to $91.58 \%$, while the non-economic motivation is equal to $8.42 \%$. In details, it is mentioned that labor Bali working in Mediterranean Shipping Company Cruise for reasons of family economic necessity of $72.79 \%$, to increase family income amounting to $15.79 \%$, to improve the self social status and family $6.32 \%$, and they work to continue their hobbies amounting to $2.11 \%$.

\section{Concepts}

In assessing the existence of Balinese women in the cruise tourism industry, it describes some of the concepts related to the research namely tourism industry, cruise ships (floating hotel), gender equality, and Balinese women.

\section{Tourism Industry}

The understanding of tourism industry in this study is a collection of diverse companies, either directly or indirectly required by tourists during travel. Companies that include the tourism industry, according to Leiper (in Pitana and Diarta, 2009: 63-65) consists of seven sectors, namely the marketing sector, transportation sector (the carrier sector), the accommodation sector, the attraction sector, the tour operator sector, the miscellaneous sector, and the coordinator sector.

http://ojs.unud.ac.id/index.php/eot

\section{Cruise (Floating Hotel)}

Cruise ship (floating hotel) is a property that uses boat/ship which is commercially managed, providing facilities and lodging services, eating and drinking, as well as other services for tourists who stay within a certain period. Cruise is a luxury hotel that can be found in the sea / ocean, which is often referred to as a cruiser or a floating hotel. Perwani (1993) states that floating hotel is a form of accommodation that is contained in the local river, canal or ocean with special characteristics, such as using boats or ships that sail from one place to another, and have a certain number of guests during the trip which has been specified. (Bagyono, 2012). mentions cruise ship (marine hotel) is a floating hotel providing room facilities, restaurants and bars which are similar to five-star hotels.

\section{Gender Equality}

Gender equality in the context of tourism is to achieve justice and equality dimension role in everyday life between women and men in the cruise tourism industry in positions, wages and others. The concept of gender is different from sex which refers to the difference between the sexes, which in turn makes the natural differences between men and women, based on their gender, universally applicable and cannot be changed. But the division of labor between men and women in society is not determined by biological factors, but rather constructed by social and cultural factors, namely power relations that are hereditarily maintained by men. These values define the roles of women and men in private life and areas of life in community (Marhumah, 2012).

\section{Balinese Women}

Balinese women in this study were women of Hindu Balinese ethnics who used to work/are still working in the cruise tourism industry. They now continue to fight for justice and role equality in everyday dimension of life in the field of tourism. Triguna (2011) states that the struggle for justice and role equality in the field of tourism is a challenge for Bali Hindu women in the future. Arniati (2012) refers to injustice in the social structure, and then manifested through 
economic, social, political and cultural life of the society. Injustice suffered by women in society ultimately stimulates the birth of emancipatory movements, hereinafter referred to as feminism movement.

\section{Theory of Motivation}

Motivation is the result of processes that are internal or external to an individual who raises enthusiastic attitude and persistence to follow the direction of certain actions. Factors in a person can be in the form of personality, attitude, experience and education or the expectations / aspirations that reach out into the future. Factors outside a person may include their neighborhood (Winardi, 2001). Maslow (1943) states that job needs and satisfactions are synonymous with biological and psychological needs, in the form of material and non-material. The basic theory is that humans are creatures who have unlimited or endless desires. The motivation tool is the unfulfiled satisfaction and tiered needs, these levels can be drawn from the lowest to the highest needs, namely: (1) physiological needs; (2) safety needs; (3) Social needs; (4) the need for respect (esteem needs); and (5) heightening the need for self-actualization (self actualization needs).

\section{Theory of Feminism}

Feminism according to various scholars is a theory that aims to fight for women to gain their rights in accordance with their functions in modern society, especially in the field of tourism. Feminist theory according to Ritzer and Goodman (2012: 403-404) is a generalization of the various systems of ideas about social life and human experience developed from the perspective centered on women. Feminist theory is developed by critical thinkers of activists or 'fighters' for the sake of women who tried to create a better life for women, hence according to critical thinkers, the struggle is for humanity.

\section{Theory of Deconstruction}

Experts claim that deconstruction is a theory that leads to humans that there is no absolute or eternal truth, the truth will be amended in accordance with circumstances and changing times. Derrida (in Lubis, 2006) through deconstruction is looking for basis of a truth in accordance with the circumstances that occurred in people's lives. Derrida is posmodernist hard liner, "strong posmodernist", who is trying to overhaul the modern world view of meaning, truth, knowledge and language in a novel way. With regard to the concept of deconstruction, Derrida (in Sutrisno and Putranto, 2005) once again makes changes to something that he can produce himself; something that is not just taking from what is already available from a tradition of thought to be criticized. To fight arbitrariness way of thinking that has always tried to find the single meaning of a text, Derrida argues that the concept of thought as a starting point of thought and effort to think of modern times should be changed totally, destroyed or deconstructed. The deconstruction of the thought building brings a new nuance.

\section{Theory of Strategic Planning}

Strategic planning is planning a business strategy to cope with the possibility of external threats and seize every existing opportunity. Strategic planning is done so that the tourism operators can see objectively the internal and external conditions, so that managers can anticipate changes in the external environment. Rangkuti (1998) states the analysis of strategic planning is one of the subject areas studied seriously in the academic field. This is done because every time there is a change. These changes can be seen from the increasingly tight competition, increasingly sophisticated technological changes, and changes in demographic conditions, which result in changes in consumer tastes rapidly.

A good understanding of the concept of strategy and other related concepts largely determine the success of the strategy developed by the company (David, 2011). These concepts include: (1) distinctive competence: actions taken by the managers of tourism in order to perform the activities better than their competitors, (2) competitive advantage: the specific activities developed by tourism operators to be more superior compared to their competitors. 


\section{Research Model}

The research model used in to discuss the presence of Balinese women in the cruise tourism industry is sketched in Figure 1.

\section{Methodology}

\section{Research Location}

The research location was Bali province, the research subjects were women who used to or were still working in the cruise tourism industry.

\section{Type and Source of Data}

Type of data collected in this study is quantitative and qualitative data. Quantitative data is data that is in the form of figures such as data on the number of migrant workers of Bali Province, migrant workers who work in the cruise tourism industry as well as other related data. Qualitative data are obtained under a variety of information from respondents stated in the research dimension as strengths, weaknesses, opportunities and threats of Balinese women, as well as economic, social, and cultural factors that affect the motivations of Balinese women to work in a cruise ship.

The data sources used are primary sources and secondary sources. From the primary sources, secondary data is obtained, that is, the data obtained from the first source is used as a sample, such as data resulting from the questionnaire about the respondents. Then, the results of the tabulated data would be displayed in tabular format. From secondary sources, secondary data was obtained, that is, the data was obtained from the competent authority such as Disparda Bali, BPS, and BP3TKI Bali which were related to the research topic.

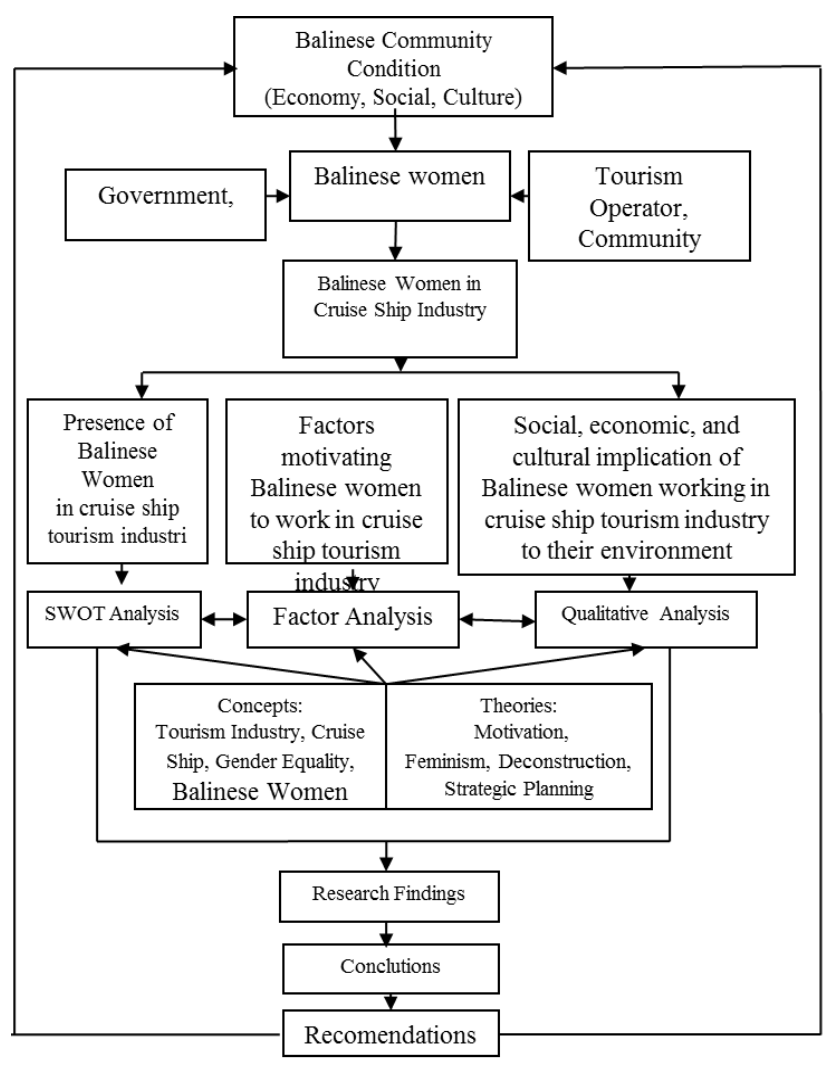

Figure 1 Research Model

\section{Data Collection Methods}

Methods of data collection conducted in the research were: observation, interviews, documentation, and FGD.

\section{Population and Sample Research}

To examine the factors that motivate women Bali to work in cruise tourism industry used factor analysis. The total sample was 200 women respondents out of a population of women who work in the cruise tourism industry in 2013 totaling 901 people. Determination of the number of samples used Solimun (2002) who revealed that the sample which is eligible to study through the analysis of factors is minimally as many as five times the number of variables. This study uses 21 variables of study, to be more representative, the sample of 200 respondents was used. Kusmayadi (2000) said that in making the number of samples studied, the accidental sampling method is used, that is, the respondents asked for information are completely encountered by chance when doing research. 
In assessing the existence of Balinese woman, it is seen from the aspect of strengths, weaknesses, opportunities and threats faced and the economic, social, and cultural implications in the cruise tourism industry in tourism and environment of life in depth, informants whose amount are not completely specified will be sought. The data collection began from one of the women having got the experience of working on a cruise ship and then spread to the other women. Data collection was considered sufficient after the information / data obtained was saturated. According to Nasution (2003), initially, the indepth study does not specify the number of informants. Selection of informants was initially done purposively, and then it was selected by means of snowball technique.

\section{Types and Variable Measurement}

Determination of variables is important to do. These research variables can describe the problems to be addressed in the object of research. Variable serves as a differentiator in order to clear in each item under study and also serves to illustrate the interconnections or have a relationship between one variable and other variables and give an overview of aligned relationship with the theory used, in this case, the theory of factors motivating Balinese women to work in the cruise tourism industry. Variables motivating Balinese women working in the cruise tourism industry are classified into three categories: economic factors as many as 7 variables (X1, X2, X3, $\mathrm{X} 4, \mathrm{X} 5, \mathrm{X} 6, \mathrm{X} 7)$, social factors 7 variables (X8, X9, X10, X11, X12, X13, X14), and cultural factors 7 variables (X15, X16, X17, X18, x19, X20, X21).

\section{Data Analysis}

\section{Descriptive Analysis}

To assess Balinese women who work in the cruise tourism industry from the aspects of the position of women working in the cruise tourism industry used descriptive statistical analysis. The position of Balinese women who work in the cruise tourism industry is described descriptively in the form of tables. Description of the levels of management positions in the industry according to Fayol (in Handayaningrat, 1990). consists of crew positions, lower manager, midle manager, and top manager. The data obtained were then described systematically with the aim of making it easier to understand Balinese women who work in the cruise tourism industry.

\section{Analysis of Factors}

In analyzing the problems of the factors that motivate Balinese women working in cruise tourism industry, the research model has been described, that is, the analysis used for this study employs confirmatory factor analysis. The use of confirmatory factor analysis aims to confirm the factors that motivate Balinese women working in cruise tourism industry in terms of economic, social and cultural aspects. In the data analysis a constructs model framework described in Figure 3.1 is expressed in an equation through factor analysis process by following a few stages as disclosed by Solimun (2002) as follows:

\section{Formulation of the problem to be a model}

Making the correlation matrix. To see whether or not there is a correlation, then do some testing among others Test Kaiser Meyer Olkin (KMO) to determine the the adequacy of the sample or measuring sample feasibility. Analysis of the factors is considered feasible if the amount of KMO> 0.05 and Barlett's test of Spericity used to test that the variables in the sample vary. Determining the accuracy of the model. Preparation of a variable is based on the results of the process on the correlation matrix above. From the results of the matrix it will appear related variables based on root characteristic (eigen value) owned. Factors that will be considered significant when eigen value of the factor is more than one $(\lambda>=$ $0,600)$. Interpretation of factors. At this stage, it is performed by grouping variables that have a loading factor (correlation between variables and the factors that shaped) high into the factor. For the interpretation of the factors in this study were assigned loading factor is minimally 0.05 . Variables that have a loading factor of less than 0.05 will be excluded from this model because it has no effect on these factors. Results of the data test are then analyzed using factor analysis. Factor analysis used in this study is confirmatory factor 
analysis. As revealed by Solimun (2002) that the confirmatory factor analysis is a priori based on theories and concepts that have been made against some of the factors that will be established, as well as latent variables included in these factors.

\section{Qualitative Analysis}

In analyzing the data of economic, social, and cultural implications of Balinese women who work in the cruise tourism industry in the environment of life, it is done through the processing and interpretation of the data which is a series of periodic review, grouping, systematization, interpretation and reification of data so that a phenomenon has social academic and scientific value. The data analysis step according to Suprayogo (2001) is an entity that is intertwined at the time before, during and after the collection of data in a form that should be to establish a general insight called "analysis". The data analysis was conducted to find the hidden reasons behind the actions of the perpetrators of social action or geared towards social significance (social meaning) of social phenomena. The focus is to find what kind of mindset that glows behind a social phenomenon or to find the rationality that lies behind the social phenomena (Bungin, 2001).

In assessing the opportunities and threats faced by women Bali in cruises, they are analyzed using SWOT (Strengths, Weaknesses, Opportunities, and Threats) analysis. Referring to Rangkuti (1998), SWOT analysis is a way to identify the various factors systematically in order to formulate the company's strategy. This analysis based on logic can maximize the strengths and opportunities, but can simultaneously minimize the weaknesses and threats. SWOT analysis considers and compares between external factors, in the form of opportunities and threats to internal factors, such as the strengths and weaknesses, so that the results of the analysis can take a strategic decision in the empowerment of women in the cruise tourism industry.

\section{Presentation of Results of Data Analysis Techniques}

The results of data analysis used in this study combine formal and informal methods. Formal data obtained will be presented either in the form of tables, graphs, or photographs. Informal data will be presented in the form of a narrative or description. Presentation of the results of the data analysis combining formal and informal methods aims to facilitate the readers in understanding it.

\section{Results and Discussion}

\section{Presence of Women Bali in Cruise}

The results showed that the presence of Balinese women labor force who works in the cruise tourism industry using a sample of 200 respondents is dominated at the position or positions as crew totaling 193 people or $96.50 \%$. The level of lower manager totals 5 people or $2.50 \%$ while the middle manager level positions totals 2 people or $1.00 \%$. In more detail, the existence of Balinese women labor respondents in the cruise tourism industry shows that the dominant position of Balinese women is the position in bars / restaurants / cocktail waitress, as many as 83 persons or $41.50 \%$. Then, the post of housemaid is as many as 27 persons or $13.50 \%$, cook as many as 18 persons or $9.00 \%$, stateroom stewardess as many as 65 persons or $32.50 \%$. The condition also shows that many Balinese women work at the food and beverage service and the housekeeping section.

The strengths owned by Balinese women who work on cruise ships such as: having a friendly attitude, smile, honest and humble, obedient, do not like to complain, responsible, and high skill. The weaknesses of Balinese women who work in the cruise tourism industry include: low motivation for the position, the ability to communicate in English is lower, confidence and managerial aspects of Balinese women labor are less prominent. The opportunities of Balinese women on a cruise ship is very high with the increasing number of cruise ships that operate, having a priority in the recruitment, and the interest of Balinese women in working on a cruise ship is still minimal while the threats faced by Balinese 
women workers, among others: labor protection is still less from the government, the labor agencies seem to work like civil servants who tend to lack in services involving TKI documents, and the agencies often provide the unfair treatment of workers who want to work on a cruise ship.

With the study of the existence of Balinese women in the cruise tourism industry in the above, and based on the strengths and opportunities of the alternative empowerment that are likely to be supportive of Balinese women empowerment is preparing human resources in tourism synergically by all related stakeholders (government, tourism actors, community). These things can be done by providing counseling and training programs for Balinese women workers who work on a cruise ship on the importance of career, mental attitude, and the ability to communicate in English so as to be able to take advantage of available opportunities optimally, and to provide a positive impact for themselves, family, nation and the state. Furthermore, to encourage the government and tourism stakeholders (employment agency to cruise ship) so that it can work together effectively to implement labor laws on the workers who work on cruise ships. The aim is that the workers who work on a cruise ship feel appreciated and comfortable given their important role as a foreign exchange earner for the country.

\section{Factors Affecting Balinese Women Working in Cruise Ship Tourism Industry}

Factors that influence Balinese women to work in cruise tourism industry are the economic, social, and cultural factors. These three factors have a significant effect on the motivation of Balinese women to work in the cruise tourism industry. The statistical analysis shows that the economic factor is the most dominant factor that encourages or motivates Balinese women to work in cruise tourism industry, then followed by cultural factor and the third is social factor.

For economic factors, the seven variables set are as follows: the Balinese are dependent on tourism (X1), cruise tourism industry contribute substantially to the economy of the people of Bali (X2), opening opportunities of

http://ojs.unud.ac.id/index.php/eot employment on cruise ships also create new job opportunities for women (X3), family economic pressure has forced Balinese women to earn a living on cruise ship (X4), by working on cruise ships Balinese women can increase family's income (X5), women work on cruise ships because they want to be independent (X6), and women feel proud if they could help earn a living for the family (X7), it significantly affects the motivation of Balinese women to work in the cruise tourism industry.

For social factors, from the seven variables defined in the study, there is one factor that society considers taboo Bali each woman working on a cruise ship (X13) did not significantly affect the motivation of Balinese women to work in the cruise tourism industry, while the other six variables are: age globalization resulted in the opening of access for women working in the public sector (X8), there is a positive attitude of the society towards women working on a cruise ship (X9), the influence of friends (social interaction) encourages women to work on a cruise ship (X10), working on a cruise ship can improve the status (prestige) of women (X11), the self quality / women education has been able to anticipate the negative impact of working on a cruise ship (X12), and the role of government in empowering women still lacking in the cruise tourism industry (X14) has a significant effect.

For cultural factors, from the seven variables defined in the study there are four variables that significantly influence the motivation of Balinese women to work in the cruise tourism industry, namely: the positive impact of working on a cruise ship is able to increase the awareness of women in preserving the local culture (X15), women working on cruise ships are able to open horizons in looking at their own culture (X16), culturally women feel marginalized because of not being given the same opportunities as men on cruise ships (X17), thick traditional Balinese culture hampers women to work on a cruise ship ( X18). While variable women want to hold a resistance to overly restrictive customs and culture (X19), working on a cruise ship can damage the morale of women's culture as well as causing negative behaviors (X20), the activities on cruise ships are loaded 
with western culture that does not comply with the Balinese culture (X21) it has no significant effect.

\section{Economic, Social, and Cultural Implications of Balinese Women Working in Cruise Ships to their Life Environment}

Implications of Balinese women who work in the cruise tourism industry in the life environment can be divided into three, namely economic, social, and cultural implications. The economic implication in the lives of Balinese women is that by working on a cruise ship they are able to help families to improve family's income. The social implication in life environment of Balinese women is that after they work on a cruise ship they able to improve their own social status / prestige and the family. The cultural implication in the lives of Balinese women is that by working on a cruise ship Balinese women are able to raise awareness in preserving their culture.

\section{Limitations of Research}

Limitations of the study were: (1) distributing the questionnaires are limited to respondents Balinese women who had worked on cruise ships which incidentally encountered when doing research in Bali, (2) interviewing to informants in Bali not be done directly on cruise ships where they work, (3) to test the consistency of the findings is advisable to conduct further research direct on cruise ships to get a detailed picture of Balinese women's life on a cruise ship.

\section{Conclusion and Recommendation}

\section{Conclusion}

Based on the analysis or study above with reference to the formulation of the problem, it can be concluded that:

1. Balinese women in the cruise tourism industry dominantly serve as crews, meaning that the quality of Balinese women workers who work in the cruise tourism industry still lies in the technical nature being in direct contact with the tourist activity. The strength owned by Balines women include being friendly, like smiling, being honest, diligent, obedient, do not like to complain, responsible, and having a high work skills. The weaknesses were having low motivation for a position, low ability of English communication, selfconfidence and managerial aspects are less obtrusive. Job opportunities in cruise ships were very high, having a priority in recruitment. The threats were that the attention of the government was still lacking in labor protection of cruise ship and the agencies seemed to give less service.

2. The factors that motivated Balinese women to work in cruise tourism industry are economic, social, and cultural factors. These three factors (economic, social, and cultural factors) had a significant effect on the motivation of Balinese women to work in the cruise tourism industry. The statistic analysis showed that the economic factor was the most dominant factor which influenced or motivated Balinese women to work in cruise tourism industry, then it was followed by cultural factors, and the third was social factors.

3. Implications of Balinese women who worked in the cruise tourism industry on the environment could be divided into three, namely the economic, social, and cultural implications. The economic implication on the lives of Balinese women was that by working in a cruise ship Balinese woman was able to help families to improve family income. The social implication for the environment of Balinese women was that after they worked on a cruise ship they were able to improve their own social status / prestige and the family. The cultural implication on the lives of Balinese women was that by working on a cruise ship Balinese women were able to raise awareness in preserving the culture.

\section{Recommendation}

Based on the conclusions and findings above, the following suggestion can be made:

1. The government should pay attention to the existance of the Indonesian workers (TKI), especially women who work in cruise ships, to the protection of their rights as well as the relevant Acts should be made clear, knowing that they serves as ambassadors of the nation that generate income for the country. 
2. The government should provide support and equal opportunities to women in accordance with their potential and the skills possessed and monitor against people (agents) who are not interested/ who hamper the course of administrative processes and documents to work abroad.

3. Women before plunging to work in cruise ships should prepare thoroughly both soft skills and hard skills to be able to win the competition on a competitive basis, given the heavy burden has been waiting to always maintain the good name of their own, family and the nation.

4. Further research should be done related to the life of Balinese women working on a cruise ship to be able to give a detailed picture of their lives.

\section{References}

Arniati, I. A. K. (2012) 'Relasi Fenimisme dengan Kearifan Lokal terhadap Perempuan', Jurnal Studi Jender Srikandi, 12(1), pp. 32-48.

Bagyono (2012) Pariwisata dan Perhotelan. Bandung: Penerbit Alfabeta.

Bungin, B. (2001) 'Metodologi Penelitian Kualitatif: Aktualisasi Metodologis ke Arah Ragam Varian Kontemporer', Jakarta: Grafindo.

David, F. R. (2011) Strategic management: Concepts and cases. Peaeson/Prentice Hall.

Handayaningrat, S. (1990) Pengantar Studi Ilmu Administrasi dan Manajemen. Jakarta: CV. Haji Masagung.

Kalpika, I. P. (1999) Perempuan dalam Industri Pariwisata: Studi Kasus di Kawasan Wisata Kuta, Ubud dan Kintamani. Udayana University.

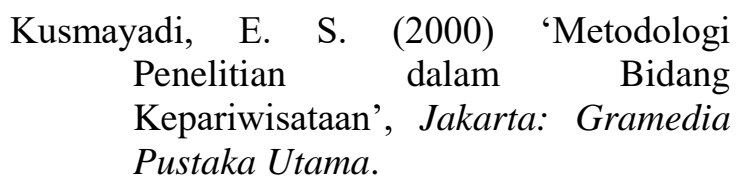

Lubis, A. Y. (2006) 'Dekontruksi Epistemologi Modern, Dari Posmodernisme Teori Kritis Poskolonialisme Hingga Cultur Science', Jakarta: Pustaka Indonesia Satu.

Marhumah, M. (2012) 'Konstruksi Gender, Hegemoni Kekuasaan, dan Lembaga Pendidikan', KARSA: Jurnal Sosial dan Budaya Keislaman, 19(2), pp. 167-182.

Maslow, A. H. (1943) 'A theory of human motivation.', Psychological review. American Psychological Association, 50(4), p. 370.

Nasution, S. (2003) 'Metode Research (penelitian ilmiah)', Jakarta: Bumi Aksara.

Perwani, Y. S. (1993) Teori dan petunjuk praktek housekeeping untuk akademi perhotelan: make up room. Gramedia Pustaka Utama.

Pitana, I. G. and Diarta, I. K. S. (2009) 'Pengantar ilmu pariwisata', Yogyakarta: Andi.

Rangkuti, F. (1998) Analisis SWOT teknik membedah kasus bisnis. Gramedia Pustaka Utama.

Ritzer, G. and Goodman, D. (2012) Teori Sosiologi Modern. Jakarta: Kencana Persada Media Group.

Sadia, I. K. and Oka, I. M. D. (2012) 'Motivasi Tenaga Kerja Bali Bekerja di Mediterranean Shipping Company (MSC)', Jurnal Sosial Humaniora, 2(3), pp. 221-236.

Sari, N. P. R. (2008) Motivasi Pekerja Perempuan Bali pada Hotel Melati di Kawasan Pariwisata Ubud Kabupaten Gianyar Bali. Udayana University.

Soedjono, L. (1986) Keadaan Angkatan Kerja Bali Menurut Sensus Penduduk 1980. Denpasar: .: FE UNUD. 
Solimun, M. S. (2002) 'Structural Equation Modelling (SEM) Lisrel dan Amos', Fakultas MIPA Universitas Brawijaya, Malang.

Sukeni, N. N. (2006) 'Dampak Pariwisata terhadap Gender di Bali', Jurnal Studi Gender Srikandi. VI.(1), pp. 1-13.

Sunarsa, I. W. (2010) 'FAKTOR FAKTOR PENENTU KEPUASAN KERJA TENAGA KERJA BALI YANG BEKERJA DI KAPAL PESIAR (STUDI KASUS DI CARNIVAL CRUISE LINE)', Volume 1 No. 1 Tahun 2010, 1(1).

Suprayogo, I. T. (2001) Metode Penelitian Sosial Agama. Bandung: PT Remaja Rosdakarya.

Sutrisno, M. and Putranto, H. (2005) Teoriteori kebudayaan. Kanisius.

Triguna, I. B. G. Y. (2011) Mengapa Bali Unik? Jakarta: Pustaka Jurnal Keluarga.

Wilkinson, P. F. and Pratiwi, W. (1995) 'Gender and Tourism in an Indonesian Village', Annals of Tourism Research, 22(2), pp. 283-299.

Winardi, J. (2001) 'Motivasi dan pemotivasian dalam manajemen', Jakarta: Raja Grafindo Persada. 